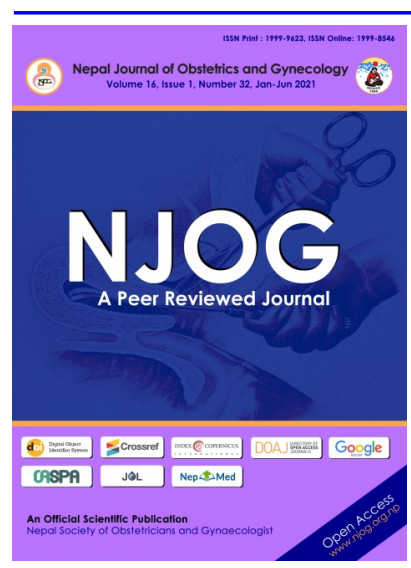

CORRESPONDENCE

Sulochana Dhakal-Rai,

Bournemouth University, Bournemouth, UK

Email:sdhakalrai@bourne mouth.ac.uk;

Received: January 21, 2021 Accepted: May 1, 2021

\section{Citation:}

Rai SD, Teijlingen EV, Regmi P, Wood J, Dangal G, Dhakal KB. Classification of Caesarean Section: A Scoping Review of the Robson classification. Nep J Obstet Gynecol. 2021;16 (32):2-9. DOI: https:// doi.org/10.3126/njog.v16i1 37409

\title{
Classification of Caesarean Section: A Scoping Re- view of the Robson classification
}

Sulochana Dhakal-Rai ${ }^{1}$, Edwin van Teijlingen ${ }^{1}$, Pramod Regmi ${ }^{1}$, Juliet Wood ${ }^{1}$, Ganesh Dangal $^{2}$, Keshar Bahadur Dhakal ${ }^{3}$

${ }^{1}$ Bournemouth University, Bournemouth, UK

${ }^{2}$ Kathmandu Model Hospital, Kathmandu, Nepal

${ }^{3}$ Karnali Province Hospital, Nepal

\section{ABSTRACT}

Caesarean section (CS) rate is rising dramatically worldwide. WHO recommended CS rate of $10-15 \%$ at populational level would not be the ideal rate at the hospitals level due to the differences on population they have been serving. At the hospital level, a perfectly effective system is necessary to understand the trends and causes of rising trends of CS as well as to implement effective measures where necessary to control the same. Hence, WHO recommended the Robson classification, which is also called the 10-group classification of CS (TGCS) as a global standard tool to assess, monitor and compare CS rates within healthcare facilities over time, and between health facilities. The Robson classification, proposed by Dr Michael Robson in 2001, is a system that classifies all women at admission at a specific health facility for childbirth into 10 groups based on five basic obstetric characteristics (parity, gestational age, onset of labour, foetal presentation and number of foetuses). This classification is easy and simple and mutually exclusive, highly reproducible, easily applicable, and useful to change clinical practice. It has many strengths such as simplicity, flexibility (further subdivisions can be made to increase homogeneity within groups). This classification helps to identify and analyse the contribution of each group to overall CS rates. It also allows distinguishing the main group of women who contributes most and least to the overall CS rates; so that the CS rates can be monitored in a meaningful, reliable, and action-oriented manner in each health facilities for optimal use of CS.

Key words: Caesarean section, Classification system, Robson classification.

\section{INTRODUCTION}

The Caesarean section (CS) rate is rising dramatically worldwide. ${ }^{1,2}$ The rising CS rate has been a major global public health issue because of its association with potential health risks to mother and baby, ${ }^{3,5}$ and adverse risks in subsequent pregnancy, ${ }^{4}$ Additionally, the rise of CS unnecessarily can cause an financial burden in the health system. ${ }^{6}$

CS rates are also rising in South Asian city hospitals. ${ }^{7,8}$ Obstetricians and hospitals need evidence-based information regarding how or why the CS rate has increased and what needs to be done for stemming the rise. The World Health Organization (WHO) recommended CS rate of 10 $-15 \%$ at population level in 1985 . $^{9}$ Although, a debate is ongoing about the optimal rate of $\mathrm{CS},{ }^{10}$ a $\mathrm{CS}$ rate greater than $10 \%$ at population lev$\mathrm{el}^{11}$ does not contribute to the preservation of maternal and foetal health. ${ }^{12}$ The population-based recommended CS rate $10-15 \%$ would not be realistic at the hospital level due to the complexity of the population they serve. ${ }^{13}$ Monitoring CS rates at hospital level by using overall CS rates is also difficult for inter- 
pretation and comparison due to variations in several factors such as differences in hospital practice, the characteristics of the local obstetric population they serve and clinical management protocols. ${ }^{13}$ The Robson classification system is a vital tool at the centre of the debate around defining the optimal rate of CS. In April 2015, WHO proposed the Robson classification to assess, monitor and compare the rates of CS rates within a health institution overtime, between different health institutions, countries and regions in a meaningful, reliable, and actionoriented manner. ${ }^{10,13-15}$ The objective of this article is to explore basic information on the Robson Classification and its use in South Asia.

\section{METHODS}

A short scoping review of articles ${ }^{16}$ highlighting the issues around Robson's Classification were searched using several bibliographic electronic databases such as PubMed, MEDLINE, EMBASE, SCOPUS, CINAHL and Web of Science as well as open access journals. Articles on Robson's Classification were searched using Medical Subject Headings (MeSH) heading such as caesarean, cesarean, c -section was combined with the specific key words such as Robson Classification using Boolean operators (and/or). Additional articles were searched from the reference list of the selected articles and organizational websites such as WHO, and open access journal databases such as Nepal journals on-line (NepJOL) and Bangladesh journals on-line (BanglaJOL) were also searched. Titles and abstracts of the identified articles were initially scanned and then, eligible full-text articles were appraised, and relevant data was extracted, then simple content analysis performed. ${ }^{17}$ Quantitative studies conducted in South Asia using the Robson classification from January 2010 to December 2020 and written in English language were included in this review. A total of 1,170 articles were found and on appraisal 26 were used in this scoping review.

\section{CLASSIFICATIONS OF CS}

There are mainly four types of classification systems commonly used to classify CS. Classification based on indications lacks of uniform definition of indications of CS, low reproducibility and insufficient comparison; based on degree of urgency has many weaknesses such as the lack of clear and unambiguous definitions that could compromise inter- rater reproducibility, comparability, and interpretation; and other bases like site and surgeon are limited by their utility. ${ }^{18}$ A systematic review conducted by WHO in 2011 determined that the Robson classification that is based on obstetric characteristics at admission is the most appropriate classification system to achieve current international and local needs. ${ }^{19}$

\section{ROBSON CLASSIFICATION}

The Robson classification, which is also called the 10-group classification of CS (TGCS), proposed by Dr Michael Robson in $2001^{20}$ is a system that classifies all women admitted at a specific health facility for childbirth into 10 groups based on five basic obstetric characteristics which are mutually exclusive and absolutely comprehensive. The system does not include the indications for CS. The maternal obstetric characteristics are: parity (nulliparous, multiparous with and without previous caesarean section); gestational age (preterm or term); onset of labour (spontaneous, induced or pre -labour caesarean section); foetal presentation (cephalic, breech or transverse); and number of foetuses (single or multiple). The 10 groups with specific obstetric characters as Robson Classification $^{16}$ are tabulated. [Table-1]

The Robson Classification categorizes all women who give birth in any health institution irrespective of route of delivery. It can be applied prospectively on admission. Every woman who gets admitted to the hospital for childbirth can be directly classified based on maternal obstetric characteristics as described above. These characteristics are usually collected routinely in maternity wards everywhere. ${ }^{13-15,19-22}$ This classification provides common initial platform for further detailed analysis within perinatal events, so that outcomes can be measured and compared. ${ }^{13-15}$

\section{STRENGTHS AND WEAKNESSES OF THE ROBSON CLASSIFICATION}

In 2014, WHO conducted a second systematic review and explored several strengths and weaknesses of Robson classification from the users of this classification. ${ }^{19}$ The main strengths of the Robson classification are: simple to implement, robust, reliable, flexible and directness of initial interpretation. Other many studies also reported that the 
Table-1: The Robson Classification

\begin{tabular}{|c|c|}
\hline Group & Obstetric population \\
\hline 1 & $\begin{array}{l}\text { Nulliparous women with a single ce- } \\
\text { phalic pregnancy, } \geq 37 \text { weeks gestation } \\
\text { in spontaneous labour }\end{array}$ \\
\hline 2 & $\begin{array}{l}\text { Nulliparous women with a single ce- } \\
\text { phalic pregnancy, } \geq 37 \text { weeks gestation } \\
\text { who had labour induced or were deliv- } \\
\text { ered by CS before labour }\end{array}$ \\
\hline 3 & $\begin{array}{l}\text { Multiparous women without a previous } \\
\text { CS, with a single cephalic pregnancy, } \\
\geq 37 \text { weeks gestation in spontaneous la- } \\
\text { bour }\end{array}$ \\
\hline 4 & $\begin{array}{l}\text { Multiparous women without a previous } \\
\text { CS, with a single cephalic pregnancy, } \\
\geq 37 \text { weeks gestation who had labour } \\
\text { induced or were delivered by CS before } \\
\text { labour }\end{array}$ \\
\hline 5 & $\begin{array}{l}5 \text { All multiparous women with at least } \\
\text { one previous CS, with a single cephalic } \\
\text { pregnancy, } \geq 37 \text { weeks gestation }\end{array}$ \\
\hline 6 & $\begin{array}{l}\text { All nulliparous women with a single } \\
\text { breech pregnancy }\end{array}$ \\
\hline 7 & $\begin{array}{l}\text { All multiparous women with a single } \\
\text { breech pregnancy including women with } \\
\text { previous CS(s) }\end{array}$ \\
\hline 8 & $\begin{array}{l}\text { All women with multiple pregnancies } \\
\text { including women with previous CS(s) }\end{array}$ \\
\hline 9 & $\begin{array}{l}\text { All women with a single pregnancy with } \\
\text { a transverse or oblique lie, including } \\
\text { women with previous CS(s) }\end{array}$ \\
\hline 10 & $\begin{array}{l}\text { All women with a single cephalic preg- } \\
\text { nancy }<37 \text { weeks gestation, including } \\
\text { women with previous CS(s) }\end{array}$ \\
\hline
\end{tabular}

Robson classification has been found to be easily applicable. ${ }^{18,21,22,24-51}$ The main weaknesses of the Robson's classification are: (1) missing data by which it cannot be classified in any 10 group as an indicator of quality of data; some suggest to create a group "99" and WHO recommends to report at footnote; (2) misclassification of women and; (3) lack of definition or consensus on core variables of the classification.

WHO has developed and published a Robson classification Implementation Manual ${ }^{14}$ in 2017 to support and guide healthcare facilities worldwide for adopting and implementing this classification. The WHO manual ${ }^{14}$ can improve common understanding to resolve the weakness of the Robson Classification, because it describes a standard approach in implementation and interpretation of the classification, including standardization of terms and definitions of core variables as well as the way of manag- ing missing data. ${ }^{14}$ Misclassification and missing data can be minimised by providing training/ guidelines, educational inputs and regular audit. ${ }^{10}$

\section{MODIFICATIONS OF ROBSON CLASSIFI- CATION}

WHO (Robson Classification Implementation Manual) has introduced the sub-classifications in Robson group 2 (2a: Labour induced and 2b: Prelabour CS), group 4 (4a: Labour induced and 4b: Pre-labour CS) and group 5 (5a: With one previous $\mathrm{CS}$ and 5b: With two or more previous CSs) to bring common point on classification.14 For the improvement of the classification for local use and to increase homogeneity within the groups, several subdivisions in each of the 10 groups have been suggested. However, group 5 (women with previous CS) has received the largest number of suggestions for sub-division. ${ }^{19}$

The Society of Obstetrics and Gynaecologists of Canada (SOGC) recommended the modified Robson criteria, which can be used to enable comparison of CS rates and indications. This modified classification of CS allows evaluation and comparison of the contributors to the Caesarean section rate and their impact. Group 2 and 4 each subdivided into A (induced labour) and B (CS before labor); Group 5 to 10 each subdivided into A (induced labor), $\mathrm{B}$ (CS before labor) and $\mathrm{C}$ (spontaneous labor). ${ }^{23}$

\section{Use of the Robson Classification in South Asia}

Use of Robson classification is growing in South Asia as witnessed by many hospital-based studies. ${ }^{24-45}$ Only a few studies have used modified Robson classification. Out of a total of 21 studies, 19 studies were retrospective and 2 were prospective. Out of a total 19 studies $^{24-43}$ conducted for assessing CS rates, one study ${ }^{44}$ was conducted for assessing trends and another ${ }^{45}$ for comparison of protocols of foetal heart rate monitoring (intermittent and continuous). However, there is paucity of large-scale studies comparing between institutions, countries and multi-centre interventions as well as further analysis of all perinatal events and outcomes adding significant epidemiological variables.

Only one study, Mittal et al $(2019)^{44}$ reported the CS trend using Robson classification in North India to assess the trend of CS rate for 3 years and it shows a static rate of $\mathrm{CS}$ in each group over the years. [Figure-1] 


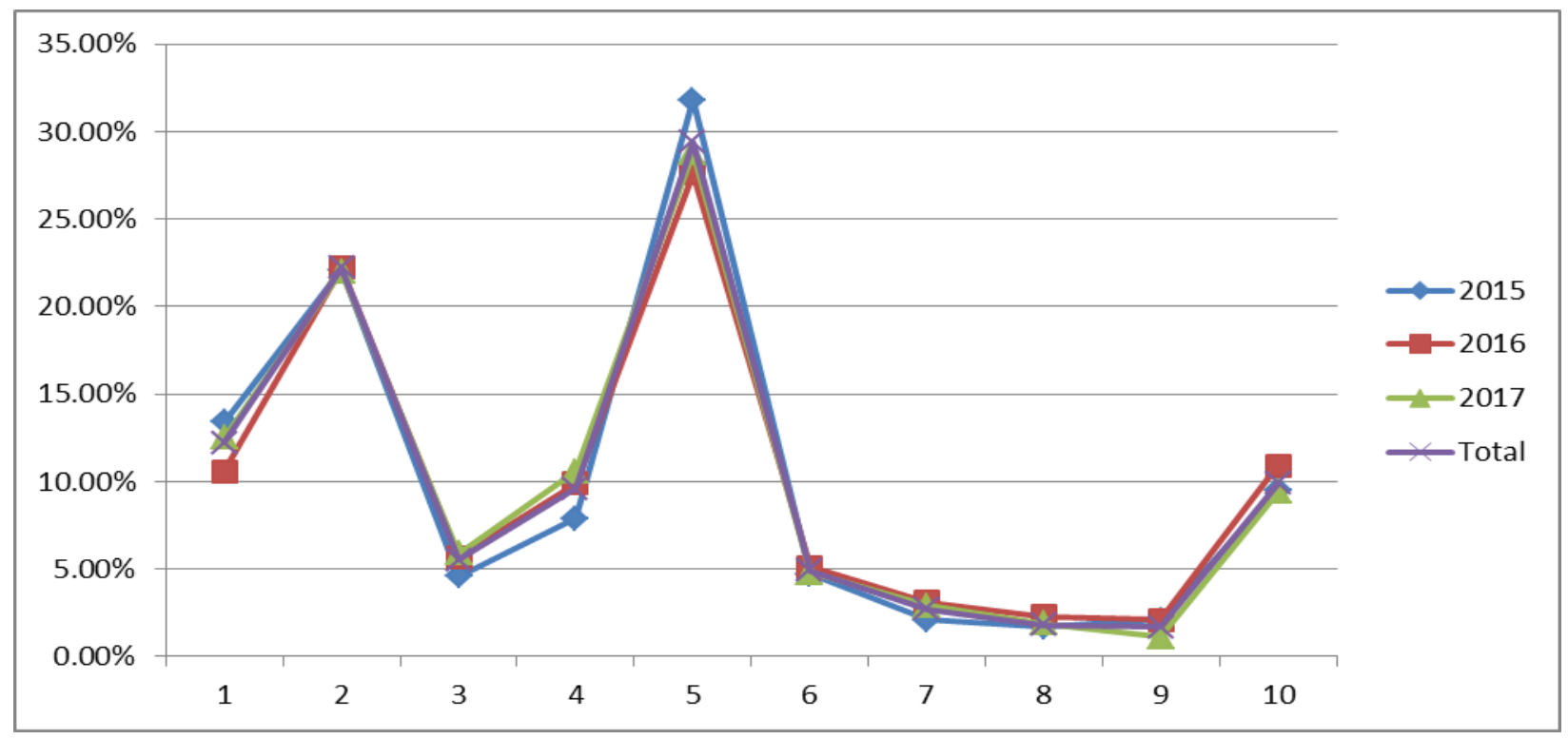

Figure-1: Trends of CS rates in Robson Groups by Mittal et al (2019)

Many hospital-based studies adapt the Robson Classification for monitoring CS rates. ${ }^{24-43}$ The group 5 is found to be the high risk group and the major contributor to overall CS rates by several studies. ${ }^{24-26,28-}$ 34,38,40,41 Few studies found Robson groups 1 to be the greatest contributor to overall CS rate. ${ }^{27,37,42-44}$ The other major contributor to overall CS rate were group two, ${ }^{24,25,28,31-33,43,44}$ group three ${ }^{35,39,42,44}$ group four, ${ }^{27}$ and group ten. ${ }^{27,44}$ Kandhari et al conducted a hospital-based study in 2019 using Robson classification among low risk cases to compare intrapartum monitoring protocols (intermittent and continuous foetal monitoring) and found decreased operative intervention and a better neonatal outcome in continuous monitoring group. ${ }^{45}$ Neonatal outcome was improved in Robson group 2A, 4A, 7A and 10A and CS was decreased in Robson group $2 \mathrm{~A} .{ }^{45}$ [Table-2]

Table-2: Contribution of each group of Robson classification to the overall CS rates.

\begin{tabular}{|c|c|c|c|c|c|c|c|c|c|c|}
\hline \multirow{2}{*}{$\begin{array}{c}\text { Authors \& year } \\
\text { (Total delivery \& CS) }\end{array}$} & \multicolumn{10}{|c|}{ Contribution made by each Robson group to the overall CS rate $\%$} \\
\hline & 1 & 2 & 3 & 4 & 5 & 6 & 7 & 8 & 9 & 10 \\
\hline $\begin{array}{l}\text { Nazneen et al. } 2011^{24} \\
(21149 ; 58.8 \%)\end{array}$ & 5.06 & 15.65 & 4.33 & $\begin{array}{c}14.4 \\
6\end{array}$ & 22.15 & 1.60 & 1.34 & 1.18 & 2.42 & 2.32 \\
\hline $\begin{array}{l}\text { Dhodapker et al. } 2015^{25} \\
(1123 ; 32.6 \%)\end{array}$ & 24.0 & 14.2 & 3.5 & 2.5 & 40.1 & 5.4 & 2.7 & 3.5 & 1.4 & 7.4 \\
\hline $\begin{array}{l}\text { Das et al. } 2016^{26} \\
(4392 ; 33.1 \%)\end{array}$ & 6.37 & 3.7 & 3.46 & 2.1 & 11.9 & 0.9 & 1.3 & 0.6 & 0.2 & 2.2 \\
\hline $\begin{array}{l}\text { Yadav et al. } 2016^{27} \\
(40986 ; 17 \%)\end{array}$ & 37.62 & 4.23 & 15.0 & 1.6 & 17.06 & 5.83 & 3.44 & 1.17 & 1.0 & 12.9 \\
\hline $\begin{array}{l}\text { Ray et al. } 2017^{28} \\
(162428.9 \%)\end{array}$ & 1.52 & 4.93 & 0.73 & 1.34 & 8.29 & 2.43 & 1.21 & 3.78 & 1.21 & 3.41 \\
\hline $\begin{array}{l}\text { Kant et al. } 2018^{29} \\
(531 ; 58.86 \%)\end{array}$ & 7.34 & 36.71 & 1.04 & 2.4 & 36.0 & 2.09 & 0.6 & 3.14 & 0.6 & 9.7 \\
\hline $\begin{array}{l}\text { Mehta et al. } 2018^{30} \\
(4785 ; 41.96 \%)\end{array}$ & 9.69 & 2.08 & 2.02 & 0.71 & 21.98 & 1.19 & 0.71 & 0.83 & 0.58 & 2.13 \\
\hline $\begin{array}{l}\text { Jogia et al. } 2019^{31} \\
(650 ; 28.3 \%)\end{array}$ & 7.61 & 21.20 & 0.54 & 4.35 & 36.96 & 8.15 & 7.61 & 2.17 & 3.26 & 8.15 \\
\hline $\begin{array}{l}\text { Shenoy et al. } 2019^{32} \\
(655 ; 27.24 \%)\end{array}$ & 15.60 & 24.33 & 0.26 & 2.26 & 27.24 & 3.70 & 1.32 & 4.23 & 1.85 & $\begin{array}{c}18.7 \\
8\end{array}$ \\
\hline $\begin{array}{l}\text { Senanayake et al. } 2019^{33} \\
(7504 ; 30.0 \%)\end{array}$ & 4.2 & 6.1 & 1.4 & 1.7 & 8.9 & 1.5 & 1.2 & 0.8 & 0.6 & 3.4 \\
\hline $\begin{array}{l}\text { Gilani et al. } 2020^{34} \\
(6155 ; 33.3 \%)\end{array}$ & 4.8 & 4.2 & 2.0 & 2.7 & 13.8 & 0.8 & 1.0 & 1.2 & 0.16 & 2.7 \\
\hline $\begin{array}{l}\text { Das et al. } 2020^{35} \\
(4394 ; 33.40 \%)\end{array}$ & 7.73 & 9.84 & 2.66 & 3.29 & 5.75 & 1.45 & 0.65 & 0.20 & 0.27 & 1.52 \\
\hline $\begin{array}{l}\text { Mittal et al. } 2019^{44} \\
(81784 ; 23.7 \%)\end{array}$ & 12.2 & 22.2 & 5.2 & 9.6 & 29.4 & 4.9 & 2.7 & 1.8 & 1.7 & 9.9 \\
\hline
\end{tabular}




\section{DISCUSSION}

The Robson classification/TGCS is an internationally accepted classification system for monitoring CS rates. The review found that use of Robson classification is rising in South Asia. It reported that Robson group 5 (All multiparous women with at least one previous $\mathrm{CS}$, with a single cephalic pregnancy, $\geq 37$ weeks gestation) is the most vulnerable group and greatest contributor to overall CS rate. Similar findings are reported in Turkey, ${ }^{15}$ Australia, ${ }^{46}$ Cana$\mathrm{da}^{47}$ and Brazil. ${ }^{48}$ Trend analysis showed Robson group 5 is expanding because of performing CS for group $1-4$ which may then require repeat $\mathrm{CS} .{ }^{15}$ Although, the Robson group 1 (Nulliparous women with a single cephalic pregnancy, $\geq 37$ weeks gestation in spontaneous labour) is low risk pregnancy group, this group was also reported as the main contributor to overall CS rate by some studies in South Asia. A similar finding is reported by other studies. $^{49,50,51}$ Robson group 2 (Nulliparous women with a single cephalic pregnancy, $\geq 37$ weeks gestation who had labour induced or were delivered by CS before labour), ${ }^{48,50,51}$ group 3 (Multiparous women without a previous CS, with a single cephalic pregnancy, $\geq 37$ weeks gestation in spontaneous labour), 48,50 group 4 (Multiparous women without a previous CS, with a single cephalic pregnancy, $\geq 37$ weeks gestation who had labour induced or were delivered by CS before labour) and group10 (All women with a single cephalic pregnancy $<37$ weeks gestation, including women with previous CS $(\mathrm{s}))^{52}$ also are major contributor to overall CS rate. These groups are those which are most likely to contribute to the high CS rate and therefore need close monitoring and could be targeted for reduction of CS rates. For example, unnecessary primary and elective CS should be avoided in low risk pregnancy such as group 1 and provision of evidencebased practice for vaginal birth after CS (VBAC).

The Robson classification itself does not show the reasons of CS but can be the common starting platform to identify the reasons of performing CS by performing further analysis of indications for CS in Robson group as required. ${ }^{55}$ Likewise, this classification can be the starting point for further detailed analysis and comparison of all perinatal events and outcomes and adding epidemiological variables. ${ }^{56}$

A study conducted by Robson et al in Dublin (2015) showed that the Robson Classification can be used as the common starting point to analyse all labour events processes (for example: rates of oxy- oxytocin usage, postpartum haemorrhage, neonatal outcomes, and duration of labour ) along with outcomes (stillbirth rate, low birth weight rate, incidence of preeclampsia, and maternal mortality ) by incorporating significant epidemiological variables (age, body mass index). ${ }^{57}$ This classification would be useful for auditing all perinatal events worldwide and it could provide an opportunity for obstetricians to learn from each other. ${ }^{57}$

The review noted that there is a deficit of largescale studies in South Asia (as in other countries) such as comparison across health institutions or regions using the Robson classification including CS trend analysis, ${ }^{15,47,48,51,53,54}$ multi-centre interventional studies ${ }^{54}$ and perinatal auditing using the Robson classification.

\section{CONCLUSIONS}

The use of the Robson classification of CS is increasing in South Asia and Robson group 5 is found to be the main contributor to overall CS rate followed by group 1 and 2. The clinical strategies/ practice could be modified to optimize CSs in health facilities.

\section{REFERENCES}

1. Betran AP, Ye J, Moller AB, Zhang J, Gulmezoglu AM, Torloni MR. The increasing trend in caesarean section rates: Global, Regional and National estimates: 1990-2014. PLOS ONE. 2016;5;11(2): e0148343. Published February 5, 2016.|DOI |Google Scholar |PubMed |Full text

2. Boerma T, Ronsmans C, Melesse DY, Barros AJD, Barros FC, Juan L, et al. Global epidemiology of use of and disparities in caesarean sections. Lancet. 2018;392(10155):1341-8. | DOI | PubMed | Google Scholar | Full text | Weblink

3. Sandall J, Tribe RM, Avery L, Mola G, Visser GHA, Homer CSE, et al. Short-term and longterm effects of caesarean section on the health of women and children. Lancet. 2018;392 (10155):1349-57. | DOI | PubMed | Google Scholar | Full text |

4. Keag OE, Norman JE, Stock SJ. Long-term risks and benefits associated with cesarean delivery for mother, baby, and subsequent pregnancies: systematic review and meta-analysis. PLoS Medicine.1002494. Published January 23, 2018.| DOI | Google Scholar | Full text |PubMed |

5. Souza JP, Gülmezoglu AM, Lumbiganon P, Laopaiboon M, Carroli G, Fawole B, et al. 
Caesarean section without medical indications is associated with an increased risk of adverse short-term maternal outcomes: the 2004-2008 WHO Global Survey on Maternal and Perinatal Health. BMC Medicine. 2010;8(1):71. | PubMed | Google Scholar | Full text |

6. Gibbons L, Belizán JM, Lauer JA, Betrán AP, Merialdi M, Althabe F. The global numbers and costs of additionally needed and unnecessary caesarean sections performed per year: overuse as a barrier to universal coverage. World Health Report. 2010;30(1):1-31. |Google Scholar | Full text

7. Dhakal Rai S, Regmi P, van Teijlingen E, Wood J, Dangal G, Dhakal K. Rising Rate of Caesarean Section in Urban Nepal. J Nepal Health Res Counc. 2019;16(41):479-80. | DOI | Google Scholar | Full text |PubMed |

8. Dhakal-Rai S, Poobalan A, Jan R, Bogren M, Wood J, Dangal G et al. Caesarean Section rates in South Asian cities: Can midwifery help stem the rise? J Asian Midwiv. 2019;6(2):4-22. Google Scholar | Full text |

9. World Health Organisation. Appropriate technology for birth. Lancet. 1985;2:436-7. | DOI | PubMed | Google Scholar | Full text | Weblink |

10.Betrán AP, Torloni MR, Zhang JJ, Gülmezoglu AM, Gulmezoglu AM. WHO statement on caesarean section rates. BJOG. 2016;123(5):667-70. |DOI | PubMed | Google Scholar | Full text | Weblink

11. Ye J, Zhang J, Mikolajczyk R, Torloni MR, Gülmezoglu AM, Betran AP. Association between rates of caesarean section and maternal and neonatal mortality in the 21 st century: a worldwide populationbased ecological study with longitudinal data. BJOG. 2016;123(5):745-53. | DOI | Google Scholar | Full text | PubMed |

12.Lumbiganon P, Laopaiboon M, Gulmezoglu AM, Souza JP, Taneepanichskul S, Pang RY, et al. Method of delivery and pregnancy outcomes in Asia: the WHO global survey on maternal and perinatal health 2007-08. Lancet. 2010;375 (9713):490-9. | DOI | Google Scholar | Full text |PubMed |

13. World Health Organization. WHO statement on caesarean section rates. Geneva: World Health Organization; 2015. | Full text | Weblink |

14. World Health Organisation. Robson classification: implementation manual. Geneva: WHO; 2017. | weblink |Full text |

15. Tontus HO, Nebioglu S. Improving the Caesarean Decision by Robson Classification: A Population-Based Study by 5,323,500 Livebirth Data. Ann Glob Health. 2020;86(1). | DOI | Google Scholar | Full text |PubMed |
16. Arksey H, O’Malley L. Scoping studies: towards a methodological framework. Int J Res Method. 2005;8(1):19-32. DOI | DOI | |Google Scholar | Full text |

17. Krippendorff K. Content analysis: An introduction to its methodology. Sage publications; 2018 May 9. | Google Scholar | Full text |

18. Torloni MR, Betran AP, Souza JP, Widmer M, Allen T, Gulmezoglu M, et al. Classifications for cesarean section: a systematic review. PloS One. 2011;6(1):e14566. | DOI | Google Scholar | PubMed | Full text |

19. Betran AP, Vindevoghel N, Souza JP, Gülmezoglu AM, Torloni MR. A systematic review of the Robson classification for caesarean section: what works, doesn't work and how to improve it. PloS One. 2014;9(6):e97769. | DOI | Google Scholar | Full text |

20. Robson MS. Classification of caesarean sections. Fetal Matern Med Rev. 2001;12(1):2339. | DOI | PubMed | Google Scholar | Full text | Weblink |

21. Vogel JP, Betrán AP, Vindevoghel N, Souza JP, Torloni MR, Zhang J et al. Use of the Robson classification to assess caesarean section trends in 21 countries: a secondary analysis of two WHO multicountry surveys. Lancet Glob Health. 2015;3:e260-70. | DOI | Google Scholar | Full text $\mid$ PubMed $\mid$

22. Betrán AP, Gulmezoglu AM, Robson M, Merialdi M, Souza JP, Wojdyla D, et al. WHO global survey on maternal and perinatal health in Latin America: classifying caesarean sections. Reprod Health. 2009;6:18. | DOI | Google Scholar ||PubMed | Full text |

23. Farineand D, Shepherd D. Classification of Caesarean Sections in Canada: The Modified Robson Criteria. J Obstet Gynaecol Can. 2012;34(10):976-9. | DOI | Google Scholar | Full text |PubMed |

24. Nazneen R, Begum RA, Sultana K. Rising trend of caesarean section in a tertiary hospital over a decade. J Bangladesh Coll Phys Surg. 2011;29(3):126-32. | DOI | Google Scholar | Full text

25. Dhodapkar SB, Bhairavi S, Daniel M, Chauhan NS, Chauhan RC. Analysis of caesarean sections according to Robson's ten group classification system at a tertiary care teaching hospital in South India. Int J Reprod Contracept Obstet Gynecol. 2015;4(3):745-9.| DOI | Google Scholar | Full text |

26. Das A, Panda S, Singh SA. An Attempt to Control the Increasing Trend of Caesarean Sec- 
ion. Obstet Gynecol Int J. 2016;5(6):00178. DOI | Google Scholar | Full text |

27. Yadav RG, Maitra N. Examining cesarean delivery rates using the Robson's ten-group classification. J Obstet Gynecol India. 2016;66(1):1-6. DOI $\mid$ Google Scholar | Full text |PubMed |

28. Ray A, Jose S. Analysis of caesarean-section rates according to Robson's ten group classification system and evaluating the indications within the groups. Int J Reprod Contracept Obstet Gynecol. 2017;6(2):447-51. | DOI | Google Scholar | Full text $\mid$ Weblink |

29. Kant A, Mendiratta S. Classification of cesarean section through Robson criteria. an emerging concept to audit the increasing cesarean section rate. Int J Reprod Contracept Obstet Gynecol. 2018;7(11):4674-7. | DOI | Google Scholar Full text

30. Mehta AV, Patel IY, Dave VP, Gupta AV. Analysis of Caesarean Section Rates According to Robson's Ten Group Classification System and Evaluating the Indications Within The Groups (At A Tertiary Care Hospital In West India). Int J Dent Med Sci Res. 2018;2(11):01-04. | Google Scholar | Full text |

31.Jogia PD, Lodhiya KK. Analysis of caesarean sections according to modified Robson's ten group classification system at a tertiary care centre in Western India. Int $\mathrm{J}$ Reprod Contracept Obstet Gynecol. 2019;8(2):433-9. | DOI | Full text |

32. Shenoy H, Shenoy ST, Anaswara T, Remash K. Analysis of caesarean delivery using Robson ten group classification system at a tertiary care teaching institute in Kerala, India. Int J Reprod Contracept Obstet Gynecol. 2019;8(5):1990-8. |DOI |Google Scholar |

33. Senanayake H, Piccoli M, Valente EP, Businelli C, Mohamed R, Fernando R et al. Implementation of the who manual for Robson classification: an example from Sri Lanka using a local database for developing quality improvement recommendations. BMJ Open. 2019;9 (2):e027317. | DOI | Full text | Google Scholar | PubMed|

34.Gilani S, Mazhar SB, Zafar M, Mazhar T. The modified Robson criteria for Caesarean Section audit at Mother and Child Health Center Pakistan Institute of Medical Sciences Islamabad Sidra. J Pak Med Assoc. 2020;70(2):299-303. | DOI | Google Scholar | Full text |PubMed |

35.Das A, Agrawal A, Bhandari S, Rajbhandari S, Rimal SP. Analysis of Cesarean Section at a Tertiary care centre in Eastern Nepal according to Robson's Ten Group classification System
(TGCS): A hospital based cross sectional study. Birat J Health Sci. 2020;5(3):1171-5. | DOI | Google Scholar | Full text |

36. Tahir N, Adil M, Fatima S, Khan S. Caesarian Sections: Frequency and indications at peripheral tertiary care hospital. Pakistan Arm Forc Med J. 2018;68(2):273-9. | Google Scholar | Full text

37. Sambharam K, Verma ML, Sambarey PW. Analysis of Caesarean section rate in a government teaching institute based on Robson's ten group classification. Int J Reprod Contracept Obstet Gynecol. 2019;8(1):140-3. | DOI | Google Scholar | Full text |

38. Preetkamal KH, Nagpal M. Is current rising trend of cesarean sections justified. Int $\mathrm{J}$ Reprod Contracept Obstet Gynecol. 2017;6(3):872 -6. | DOI | Google Scholar | Full text |

39. Goonewardene M, Bhabu B, Chethiyawardhana I, Kalinga SS, Wickramasooriya J, Dandeniya R. Increasing Caesarean Section Rates in a Teaching Hospital in Sri Lanka and the use of a Modification of Robson's Ten Group Classification System for Caesarean Sections. Gin Pol Med Project. 2016;40:009-15. | Google Scholar | Full text |

40.Goonewardene M, Peiris M, Kariyawasam S, Mallawaaratchi S, Kadawathage D, Sanjeewa L et al. Analysis of high caesarean section rates: the second step after audits using the Ten Group Classification System. Ceylon Med J. 2017;62:149-58. | DOI | Google Scholar | Full text | PubMed |

41.Malla RV, Hamal C, Neupane B, Khatri R. Analysis of Cesarean Section Using Robson's 10-Group Classification at a Tertiary Level Hospital in Nepal. J Shree Birendra Hosp. 2018;17(2):4-11. | DOI | Google Scholar | Full text

42.Poudel R, Dangal G, Karki A, Pradhan HK, Shrestha R, Bhattachan K, et al. Assessment of Caesarean Section Rates at Kathmandu Model Hospital Using the Robson's Ten Group Classification System. J Nepal Health Res Counc. 2019;17(4):491-4. | DOI | Google Scholar Full text $\mid$

43. Amatya A, Paudel R, Poudyal A, Wagle RR, Singh M, Thapa S. Examining stratified cesarean section rates using Robson classification system at Tribhuvan University Teaching Hospital. J Nepal Health Res Counc. 2013;11 (3):255-58. | DOI | Google Scholar | Full text | PubMed |

44. Mittal P, Pandey D, Suri J, Bharti R. Trend prediction for cesarean deliveries based on Robson classification system at a tertiary referral unit of North India. J Obstet Gynecol India. 2019;11:1- 


\section{8. | DOI | Google Scholar | Full text | PubMed |}

45.Kandhari KV, Mayekar RV, Bhosale AA, Nandanwar YS. Segregation of Patients for Intrapartum Monitoring, using Robson's Classification. J Clin Diagnos Res. 2017;11(4):QC15. DOI Google Scholar Full text PubMed

46. Tanaka K, Mahomed K. The Ten-Group Robson Classification: A Single Centre Approach Identifying Strategies to Optimise Caesarean Section Rates. Obstet Gynecol Int. 2017;2017:5648938. | DOI | Google Scholar | Full text | PubMed |

47.Kelly S, Sprague A, Fell DB, Murphy P, Aelicks $\mathrm{N}$, Guo $\mathrm{Y}$, et al. Examining caesarean section rates in Canada using the Robson classification system. J Obstet Gynaecol Canada. 2013;35 (3):206-14. | DOI | Google Scholar | Full text | PubMed |

48. Rudey EL, do Carmo Leal M, Rego G. Cesarean section rates in Brazil: trend analysis using the Robson classification system. Medicine. 2020;99 (17). | DOI | Google Scholar | Full text | PubMed

49.Tognon F, Borghero A, Putoto G, Maziku D, Torelli GF, Azzimonti G, et al. Analysis of caesarean section and neonatal outcome using the Robson classification in a rural district hospital in Tanzania: an observational retrospective study. BMJ open. 2019;9(12):e033348. | DOI | Google Scholar | Full text $\mid$ PubMed |

50.Baral G, Shrestha A, Sah A, Gupta AK. Robsons Ten Group Classification of Cesarean Section at a Tertiary Center in Nepal. J Nepal Health Res Counc. 2021;19(1):91-6. DOI Google Scholar PubMed Full text

51.Kacerauskiene J, Bartuseviciene E, Railaite DR, Minkauskiene M, Bartusevicius A, Kliucinskas $\mathrm{M}$, et al. Implementation of the Robson classification in clinical practice: Lithuania's experience. BMC Pregnancy Childbirth. 2017;17(1):1-5. DOI | Google Scholar | Full text | PubMed |
52. Parveen R, Khakwani M, Naz A, Bhatti R. Analysis of Cesarean Sections using Robson's Ten Group Classification System. Pak J Med Sci. 2021;37(2). | DOI | Google Scholar $\mid$ Full text $\mid$

53. Tapia V, Betran AP, Gonzales GF. Caesarean section in Peru: analysis of trends using the Robson classification system. PLoS One. 2016;11(2):e0148138. | DOI | Google Scholar | Full text $\mid$ PubMed $\mid$

54. Smith DC, Phillippi JC, Lowe NK, Breman RB, Carlson NS, Neal JL, et al. Using the Robson 10-group classification system to compare cesarean birth utilization between US centers with and without midwives. J Midwifery Women's Health. 2020;65(1):1021. | DOI | Google Scholar | Full text | PubMed

55. Robson M, Hartigan L, Murphy M. Methods of achieving and maintaining an appropriate caesarean section rate. Best Pract Res Clini Obstet Gynaecol. 2013;27(2):297-308. | PubMed | Google Scholar | Full text | DOI |

56. Robson M. The Ten Group Classification System (TGCS)-a common starting point for more detailed analysis. BJOG. 2015;122 (5):701-701.| DOI | Google Scholar | Full text | PubMed |

57. Robson M, Murphy M, Byrne F. Quality assurance: The 10Group Classification System (Robson classification), induction of labor, and cesarean delivery. Int J Gynecol Obstet. 2015;131:S23-7. | DOI | Google Scholar Full text | PubMed | 